\title{
Awareness of biological warfare in Nigeria
}

\author{
Aliu Ademoh Ohiare \\ Department of Biology, Federal College of Education, P.M.B 1026, Okene, Kogi State, Nigeria
}

\begin{abstract}
First let me state categorically that the Republic of Nigeria is completely unprepared to detect, deter or defend against an attack utilizing bioweapons to cripple any of its critical complexes including government, among oil \& gas, banking and health services. This lack of capacity of Nigeria biodefense may currently being exploited and probed by interest determined to undermine the unity of the Republic of Nigeria and attack our interest in the region. Science has the potential for creating even more effective and horrific biological weapons. The U.S government should assist Nigeria in establishing a biodefense program in Nigerian university, modeled after biodefense program at George Mason University, which would provide students with a background in the science and technology of biodefense and the specialized areas of threat assessment, on proliferation and medical and public health preparedness.
\end{abstract}

Keywords: biological warfare; biodefense; Nigeria

\section{INTRODUCTION}

Biological warfare, also known as germ warfare is the use of biological toxins or infectious agents such as bacteria, viruses and fungi with intent to kill or incapacitate humans, animals or plants as an act of War. Biological Weapon (BW) is living-organisms or replicating entities (Viruses) that reproduce or replicate within their host victims. Entomology (insect) warfare is also considered a type of Biological Weapons (Wallerstein, 2012).

Biological weapons may be employed in various ways to gain a strategic or tactical advantage over an adversary, either by threats or by actual deployments. Like some of the chemical weapon, biological weapons may also be useful as area denial weapons. These agents may be lethal or non-lethal and may be targeted against a single individual, a group of people or even an entire population. They may be developed, acquired, stockpiled or deployed by nation states or by non-national groups. In the latter case, or if a nation-state uses it clandestinely, it may also be considered bioterrorism (Malcolm, 2006). There is an overlap between Biological Weapons and chemical warfare, as the use of toxins produced by living organisms is considered under the provision of both the biological weapons convention. Toxins and psychochemical weapons are often referred to as midspectrum agents unlike bioweapons, these midspectrum agents do not reproduce in their hosts and are typically characteristized by shorter incubation periods.

Rudimentary forms of biological warfare have been practiced over and over again throughout history. During the $6^{\text {th }}$ century BC, the Assyrians poisoned enemy wells with a fungus that would render the enemy delirious. In 184BC, Hannibal of Carthage has clay post filled with venomous snakes and instructed his soldiers to throw the pots onto the decks of 
Pergamene ships. Even history has it that Ebira warrior's (in Kogi State, Nigeria), use a pot of honey bees against their enemy during war. Historical accounts from medieval Europe detail the use of infected animal carcasses by Mongols, Turks and other groups of infect enemy water supplies. In 1346, the bodies of Mongol (WHO, 1970) warriors of the Golden Horde who had died of plaque were thrown over the walls of the besieged Crimean city of Kaffa. It has been speculated that this operation may have been responsible for the advent of Black Death in Europe (Adrienne, 2003). The last known incident of using plague corpses for Biological Weapons purposes occurred in 1710, when Russian forces attacked the Swedes by flinging plague - infected corpses over the city walls of Reval (Eitzen, 2004).

The British army at least once attempted to use smallpox as a weapon, when they gave contaminated blankets to the Lenape during Pontica's War $(1763-66)$. It is suspected by Ward Churchchill, but not confirmed that Biological Weapons was used against Native Americans at other times as well. ( )

The advent of the germ theory and advances in bacteriologic brought a new level of sophistication to the theoretical use of bio-agents in war. Biological sabotage in the form of anthrax and glanders was undertaken on behalf of the imperial German government during World War (1914 - 1918), with indifferent results.

According to Robert (2006), use of such bio-weapons was banned in international law by the General protocol of 1925. The 1972 Biological and Toxin Weapons Convention (BWC) extended the ban to almost all production, storage and transport. However, both the Soviet Union and Iraq secretly defied the treaty and continued research and production of offensive Biological Weapons, despite being signatories to it. Major public proof of the Soviet program, called Bio preparat, came when Dr. Kanatjan Alibekov, its first deputy director, defected to the U.S in 1992.

\section{OVERVIEW OF BIOLOGICAL WARFARE}

Offensive biological warfare, including mass production, stockpiling and use of Biological Weapons, was outlawed by the 1972 Biological Weapons Convention (BWC). The rationale behind this treaty, which has been ratified or acceded to by 165 countries as of 2011 , is to prevent a biological attack which could conceivably result in large number of civilian fatalities and cause severe disruption to economic and societal infrastructure (Kelle, 2007). Many countries including signatories of the BWC currently pursue research into the defense or protection against BW, which is not prohibited by the BWC.

A nation or group that can pose a credible threat of mass causality has the ability to alter the terms on which other nations or groups interact with it. Biological Weapons have the potential to create a level of destruction of loss of life far in excess of nuclear, chemical or conventional weapons, relative to their mass and cost of development and storage. Therefore biological agents may be useful as strategic deterrents in addition to their utility as offensive weapons on the battle field (Koenig, 2006). As a tactical weapon for military use, a significant problem with a Biological Weapons attack is that it would take days to be effective and therefore might not immediately stop an opposing force. Some biological agents (small pox, measles pneumonic plague) have the capability of person-to-person transmission via aerosolized respiratory droplets. This feature can be undesirable, as the agents may be transmitted by this mechanism to unintended populations, including neutral or even friendly force. While contaminant of or terrorist organizations, it remains a significant concern for the military and civilian populations of virtually all nations. 
The use of Biological warfare became more sophisticated during the $19^{\text {th }}$ century. The conception of Koch's postulates and the development of modern microbiologist during $19^{\text {th }}$ century made it possible the isolation and production of stocks of specific pathogens (Robertson, 1995).

During World War I, there were reports of attempts by Germans to ship horses and cattle inoculated with disease- producing bacteria such as Bacillus anthraces (anthrax) and Pseudomonas pseudomallei (glanders), to the U.S.A and other Romanian sheep that were designated for export to Russia. Other plague in St. Petersburg in Russia followed (Hugh, 1992).

In 1924, a subcommittee of the Temporary Mixed Commission of the League of Nations, in support of Germany, found no hard evidence that the bacteriological arm of warfare had been employed in war (Stockholm, 1971). The centre of the Japanese biowarfare program was known as "Unit 731 and was located in Manchuria near the town of Pingfan (Eitzen, Takafuji, 2004). The Japanese program consisted of more than 150 buildings Pingfan, 5 staellite camps and a staff of more than 3000 scientists. Organisms and diseases of interest of the Japanese program were B. anthracis, Neisseria meningitides, Vibrio cholerae, Shigella spp and Versiniapestic (Harris, 1994). More than 10, 000 prisoners are believed to have died as a result of experimental infection during the Japanese program between 1932 and 1945. at least 3000 of these victims were prisoners of war, including Korean, Chinese, Monogolian, Soviet, American, British and Australian soldiers (Harris, 1994). During the Korean War, the Soviet Union, China, and North Korea accused the USA of using agents of biological warfare against North Korea.

\section{BIOLOGICAL WEAPONS CONVENTION AND NIGERIA}

At the first review conference of state parties to the Biological Weapons Convention (BWC), in 1980, Nigeria reported that it "had compiled fully with its obligation under the 1972 Biological Weapons Convention.

In 1995, during a debate on the committee of the UN General Assembly, Nigeria stated that it was committed to the total prohibition of Biological Weapons. At the fourth review conference of states parties to the Biological Weapons Convention in 1966, Nigeria stated: "it is our hope that all weapons of mass destruction be they biological ... will be under ban, their production prohibited, their transfer and use outlawed" (Onyenekenwa, 2012).

Biological agents pose a high risk should not be toyed with, said by the then secretary to the Government of the Federation (SGF) Yagale Ahmed made the announcement at a regional workshop in Abuja on implementation of BWC for West and Central Africa. The BWC is an international treaty aimed at handling biological agents in ways that do not pose threat to the populace. Misuse of biological agents could take a much greater toll on any pollution by way of increased illnesses, long term disability and death. Strategy for successful defense against any threat in public health is early detection, identification, monitoring of disease and toxins in a community as well as treatment (Onyenekenwa, 2012). For example smallpox is a highly contagious and deadly disease caused by the variola virus. It was estimated to have infected millions of people in the $20^{\text {th }}$ century before it became the only human infectious disease ever to be completely eradicated. After eradication of smallpox, the World Health Organization (WHO, 1970) pre-1979 poster from Western Nigeria recommended that all remaining specimen of variola be destroyed or sent to containment reference laboratories located in the U.S. and Russia. Today, the only potential source of 
small pox infection is an unintentional laboratory release or a biological attack. Small pox is considered one of the most serious bioterrorists threats. It was used as a Biological Weapons during the French and Indian wars, (1954 - 1767) (Henderson, 2007).

The natural biological weapons that resulted to famine in Nigeria during $20^{\text {th }}$ century, desert locust plagues that voracious eat almost all vegetation. The desert locust (Schistocerca gregaria) caused significant crop losses in West Africa and today a negative impact on food security in the region (Vallobana, 2008). The other Biological warfare mostly to reduce African-American population is HIV/AIDs according to Dr. Boyd E. Graves a prominent lawyer in California United States. He file a suit against U.S. Government that the HIV virus, the virus that causes AIDs is virus that was manufactured in American laboratories between 1962 and 1978. Dr. Grave's claims he has hundred of government documents providing HIV/AIDs was designed as biological terrorism against African-American. His action was initially brought in the U.S. Supreme Court Case No. 00-9507. Researchers have long suspected that HIV arose as a result of viral "cross-species jump" from primates to humans. According to Graves, the scientific evidence is compelling. He says: "the HIV/AIDs virus was manufactured as a designer bi-product of the US special virus programme (Gurney, 2003).

In Kano, 13 August 2008, a highly pathogenic strain of avian influenza never previously in sub-Saharan African has been detected in northern Nigeria but local health officials have downplayed the significance. It is likely the new strain might have been introduced to the country by migratory birds. Avian flue was first recorded in Nigeria on a farm in Jaji in northern Kaduna state in February 2006. From there it quickly spread to 25 out of the country's 36 states, with Kano being the worst hit.

Avian flu can transfer to human and if probably kill the system of infected person from the infected bird. Also 1998, the World Health Organization estimates there were ever 365,000 new cases of polio; by early 2003, the rate of infection had decline to less than 1,000 new cases worldwide due to a vigilant vaccination effort (Robert, 2005). That trend was interrupted in August, 2003, however, when unfounded allegations of contaminated vaccines that would lead to sterility, hinder testicular development and because AIDS ran rampant in Northern Nigeria Kano State.

\section{CONCLUSION}

Developing recommendations for prophylaxis and treatment of emerging and bioterrorism pathogens can be especially difficulty. Data on the effects of some emergency response countermeasure treatments are limited especially on pregnant women and fetuses. Emergency response planners should include recommendations for treatment in pre-vent response plans, rather than creating them during an emergency. Clinicians should become familiar with recommendations for prophylaxis and treatment of persons with emerging and bioterrorism pathogens so that they will be prepared to discuss risks and benefits of recommended treatments with patients. Long-term goals should include evaluation of the effects of emergency response treatments, research and development of safer and effective medications when warranted. 


\section{Recommendation}

The above findings suggest the need for certain steps related to preparedness for biological agents attacks and this include:

* Improved communication is needed between animal health and human health professionals, so that sentinel events could be rapidly detected. Such improvement would mean overcoming existing barriers to communication; a recent survey found that physicians and veterinarians communicate little about zoonotic issues.

* Also an adequate surveillance network should be developed to detect unusual health events in animal populations. Data on usual trends is missing for most animal species that could be potential sentinels. Whether public health resources can be committed to gathering such baseline data remains an open question.

* The U.S. government should assist Nigeria in establishing a biodefense program in Nigerian university, modeled after the biodefense program at George Mason University, this would provide students with a background in the science and technology of biodefense and the specialized areas of threat assessment, onproliferation and medical and public health preparedness.

* Better approaches for intervention are needed to be able to stem the propagation and amplification of an introduced biological warfare agent into a wild or domestic animal population. The US experience with West Nile virus reflects the difficulties of controlling an emerging zoonotic threat as it spreads through animal population.

* There is need for additional research to fill knowledge gaps about animals as sentinels of human disease threats, including data on relative susceptibilities and exposure pathways for animal species living near human and populations.

\section{References}

[1] Centers for Disease Control and Prevention (CDC, 2000). Biological and chemical terrorism: Strategic plan for preparedness and response. Recommendations of the CDC Strategic Planning Workgroup. Morbidity and Mortality Weekly Report (MMWR) 49:1-4.

[2] Eitzen E. M, Takafuji E. T. (2004). Historical overview of biological warfare. In: Sidell F.R. editors. Medical aspects of chemical and biological warfare. Washington, DC: Borden Institute. p. 415-423.

[3] Gargan T. P. (1988). Vector potential of selected North American mosquito species for Rift Valley fever virus. Am. J. Trop. Med. Hygiene, 38; 440-446.

[4] Howard J. J. (1996). Evidence for multiple foci of eastern equine encephalitis virus (Togaviridae: Alphavirus) in Central New York State. J. Med. Entomol., 33: 421-432.

[5] Kelle A. (2007). Synthetic Biology \& Biosecurity Awareness in Europe. Bradford Science and Technology Report, No. 9.

[6] Koenig R. (2006). The Fourth Horseman: One Man's Secret Campaign to Fight the Great War in America, Public Affairs.

[7] Onyenekenwa C. E. (2012). Biological weapon-agents for life and environmental destruction. Research Journal of environmental toxicology, 6: 65-87. 
[8] Rabinowitz, P. (2006). Animal as sentinels of bioterrorism agents. Emerging Infect. Dis. $J ., 12(4): 647-652$.

[9] Robert F. (2005). "Deterring terrorism: It can be done". International security on biological weapons, 30: 95-98.

[10] Robertson A. G. (1995). From asps of allegations: biological warfare in history. Mil Med., 160: 369-373.

[11] Stockholm International Peace Research Institute (SIPRI, 1971). The Problem of Chemical and Biological Warfare, Vol. I: The Rise of CB Weapons. New York: Humanities Press.

[12] Vallebona C. (2008). Large-scale climatic patterns forcing desert locust upsurges in: West Africa Climate Research, 37: 35-41.

[13] Wallerstein M. B. (2012). Science in an age of terrorism. Science, 297, 2169 [pubMed].

[14] White S. R. (2002). Medical management of vulnerable populations and co-morbid conditions of victims of bioterrorism. Emerging Med. Clin. North Am., 20: 365-392. Aspects of Chemical and Biological Weapons. Geneva, Switzerland.

[15] Piotr Daniszewski, International Letters of Social and Humanistic Sciences 1 (2013) 28-34.

[16] Piotr Daniszewski, International Letters of Social and Humanistic Sciences 3 (2013) 54-68.

[17] Piotr Daniszewski, International Letters of Social and Humanistic Sciences 9 (2013) 65-73.

[18] Piotr Daniszewski, International Letters of Social and Humanistic Sciences 9 (2013) 74-83.

[19] Piotr Daniszewski, International Letters of Social and Humanistic Sciences 9 (2013) 84-94. 